\title{
Effects of Different Conditions on The Vase Life of Orchis palustris
}

\author{
Serkan ÖZER ${ }^{1}$, Hasan YILMAZ, ${ }^{1}$ Mehmet Akif IRMAK ${ }^{1}$, Murat ZENGİN²
}

\begin{abstract}
Orchis palustris grows naturally in Erzurum and has drawn attention as new cut-flower. This study was carried out to determine the vase life of Orchis palustris under different conditions including the use of chemical preservatives; (8-HQ, $\mathrm{AgNO}_{3}$ sodium benzoate, sugar, $\mathrm{AlSO}_{4}$ and kinetin). The results indicated that the $\mathrm{B}$ solution prolonged the life of the Orchids by 23 days, which is 8.4 days longer than the control. It was also found that Orchis palustris which stays alive for up to14.6 days even in tap, can be a cut as flower and vase plant with life length of its flowers and exclusive size of its flowers.
\end{abstract}

Keywords: Cut flower, Erzurum, Orchis palustris, solution, vase life

\section{Orchis palustris'in Vazo Ömrü ve Diğer Bazı Özellikleri Üzerine Değişik Kimyasal Karışımlarının Etkisi}

ÖZET: Orchis palustris Erzurum ilinde doğal olarak yetişmekte ve çiçeklerin güzellikleri ile yeni bir kesme çiçek türü olarak dikkatleri çekmektedir. Çalışma Orchis palustris' in biri Control (musluk suyu) olmak üzere dört ayrı solüsyonda (8-HQ, $\mathrm{AgNO}_{3}$ sodyum benzonat, şeker, $\mathrm{AlSO}_{4}$ ve kinetin) vazo ömürlerini belirlemek amacıyla yapılmıştır. Çalı̧̧ma sonucunda Orchis palustris' in B solüsyonunda 23.0 gün vazo ömrü ile Control solüsyonuna göre 8.4 gün (57.5\%) artış sağladığı gözlenmiştir. Ayrıca Control solüsyonu olan musluk suyunda bile 14.6 gün yaşayan Orchis palustris' in gerek çiçek ömrü gerekse de etkileyici çiçek boyu ve güzellikleri ile iyi bir kesme ve vazo çiçeği olabileceği belirlenmiştir.

Anahtar Kelimeler: Erzurum, kesme çiçek, Orchis palustris, solüsyon, vazo ömrü

Atatürk Üniversitesi, Mimarlık ve Tasarım Fakültesi, Peyzaj Mimarlı̆ı̆ , Erzurum, Türkiye

Pamukkale Üniversitesi, Mimarlık ve Tasarım Fakültesi, Peyzaj Mimarlığı Bölümü, Denizli, Türkiye

Sorumlu yazar/Corresponding Author: Serkan ÖZER, sozer2000@hotmail.com 


\section{INTRODUCTION}

Flowers reveal the distinctive beauty of nature. Naturally growing flowers have been cultivated for many years for their various characteristics including medicinal and aesthetic. People living in urban environments tend to use different varieties of flowers either in or out of their houses. Cut-flowers are chosen as the indicative symbol of love for special events. The floral industry has seen an increase in demand in recent years. Cut flowers account for $80 \%$ of the commercial flower market in the world (Groot, 1998). Due to its diverse eco-geographic characteristics, Turkey contains over 9000 different plant species, 3000 of which are endemic (Kiziroğlu ve ark., 1992). In spite of this richness, the country is not a key producer in the flower trade. According to the AIPH (2008), Turkey was ranked $24^{\text {th }}$ in the world in 2007 for ornamental plant production (Anonymous 2009)

Orchid production in Turkey is below the level of demand in the world. However, orchids are popular tropical cut-flowers and are now marketed globally (Hew, 1994). Orchids rank fourth among cut flowers in EU countries with an export rate of 151744 stems and 85172 million Euros. Orchid production has not seen an increase in Turkey despite increases in imports in recent years. In 2008, it was the second most imported flower following the rose (Anonymous, 2009). In the floral industry, aesthetic conditions and vase life are among the top criteria required by wholesale growers. Several studies have shown the effects of different chemicals on flower length and shelf life. (Y1lmaz, 1991; Ketsa et al., 2001; Sahamantak and Pathania, 2003; Sing et al., 2004; Al-Humaid; 2004, Darras, 2005; Macnish et al., 2008; Machaka-Houri et al., 2012; Gomiz el al., 2013).

The objective of this study was to determine the length of vase life and use possibilities of Orchis palustris as cut-flowers, which is a native plant in the northern area of the city of Erzurum, appreciated for its beauty and flower length. In addition, prolonging the vase life of Orchis palustris using chemical solutions by investigated.

\section{MATERIAL AND METHODS}

In this study, Orchis palustris was the primary material. The plants were grown naturally in prairie and wet lands located $20 \mathrm{~km}$ north of the city of Erzurum in the Northern Anatolia region of Turkey. (Eken et al., 2005). Cultivated in their native setting, root the length measurement is between 40 and $80 \mathrm{~cm}$, petals are 18 to $20 \mathrm{~cm}$ and flower stems are 3.0 to $3.5 \mathrm{~cm}$. To obtain homogeneous samples, fully mature plants with similar features were sampled (length: 50-60 cm, petal: 18$20 \mathrm{~cm}$, flower stems: 3-3,5 cm) (Figure 1). The plants were $90 \%$ in bloom at the flowering stage. Stems were cut at ground level in their natural habitat then were transported to the laboratory in water and protected from light during transportation.
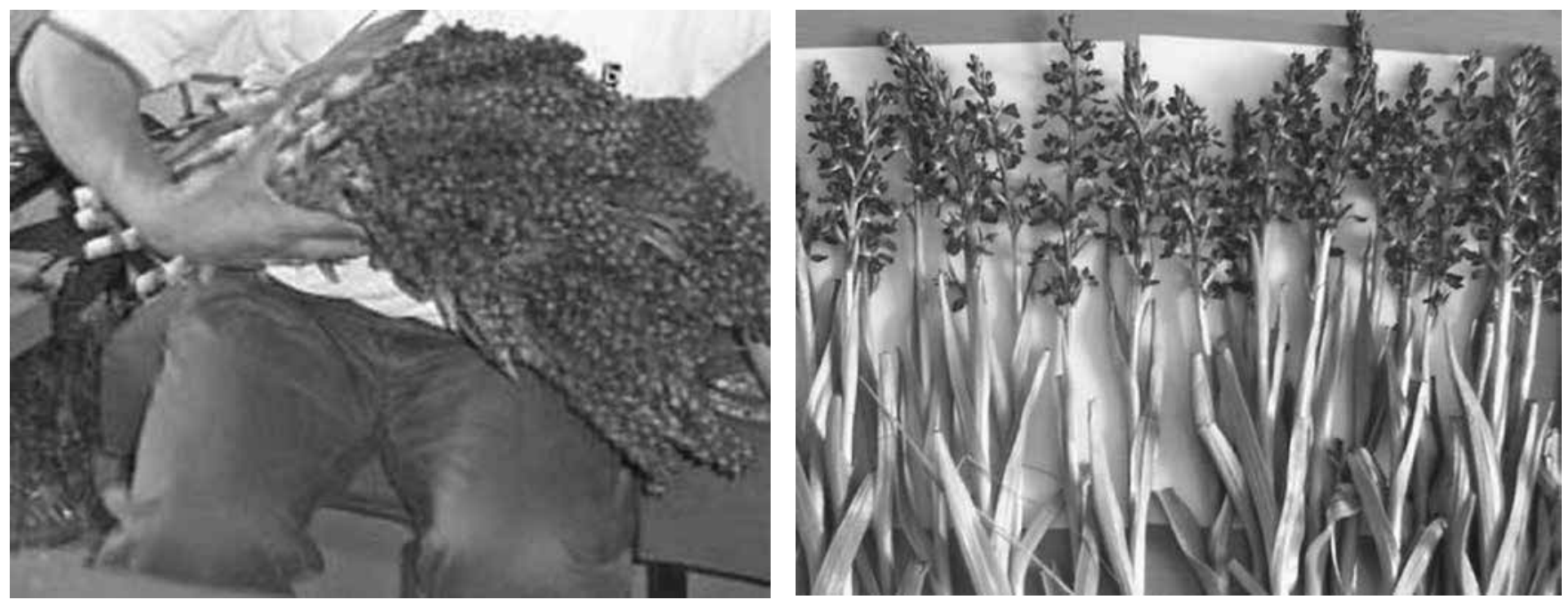

Figure 1. Preparation of samples for vase experiment. 
Preparation of solutions: Solutions were prepared considering the principles of Ketsa and Boonrote (1990), Yilmaz (1991) and Ketsa et al. (1995). Four different solutions (A), $100 \mathrm{mg} \mathrm{L}^{-1}$ 8-HQ, $50 \mathrm{mg} \mathrm{L}^{-1} \mathrm{AgNO}_{3}, 60 \mathrm{mg} \mathrm{L}^{-1}$ sodium benzoate, $40 \mathrm{~g} \mathrm{~L}^{-1}$ sugar, $25 \mathrm{mg} \mathrm{L}^{-1} \mathrm{AlSO}_{4}$ and $5 \mathrm{mg} \mathrm{L}^{-1}$ kinetin; (B), $150 \mathrm{mg} \mathrm{L}^{-1} 8-\mathrm{HQ}, 100 \mathrm{mg} \mathrm{L}^{-1} \mathrm{AgNO}_{3}, 80 \mathrm{mg} \mathrm{L}^{-1}$ sodium benzoate, $50 \mathrm{~g} \mathrm{~L}^{-1}$ sugar, $20 \mathrm{mg} \mathrm{L}^{-1} \mathrm{AlSO}_{4}$ and $10 \mathrm{mg} \mathrm{L}^{-1}$ kinetin; (C), $300 \mathrm{mg} \mathrm{L}^{-1} 8-\mathrm{HQ}, 75$ $\mathrm{mg} \mathrm{L}^{-1} \mathrm{AgNO}_{3} 100 \mathrm{mg} \mathrm{L}^{-1}$ sodium benzoate, $60 \mathrm{~g} \mathrm{~L}^{-1}$ sugar, $15 \mathrm{mg} \mathrm{L}^{-1} \mathrm{AlSO}_{4}$ and $5 \mathrm{mg} \mathrm{L}^{-1}$ kinetin; and in the fourth solution (Control) tap water were used. Mixtures of A, B and C were diluted in $1 \mathrm{~L}$ - vase full of tap water. Orchis palustris samples were cut with a stem length of 25 to $30 \mathrm{~cm}$ and flower length of
19 to $21 \mathrm{~cm}$ before being taken to laboratory. A total five flowers were put into $1-\mathrm{L}$ vases. The Wilson Colour Chart catalogue was used for the definition of flower colours. Colour of the flower samples was detected to be Amethyst Violet 35 (Wilson, 1938).

Preparation of laboratory conditions: Vases were kept under shade conditions to protect flowers from direct sun light (Figure 2). Special care was taken to prevent humidity and temperature changes. During the study, the laboratory was ventilated for two hours every other day. Changes in the $\mathrm{pH}$ of the solutions were measured at the beginning, middle and end of the study period. The length of flowers and flower stems, stem thickness and solution levels were measured.

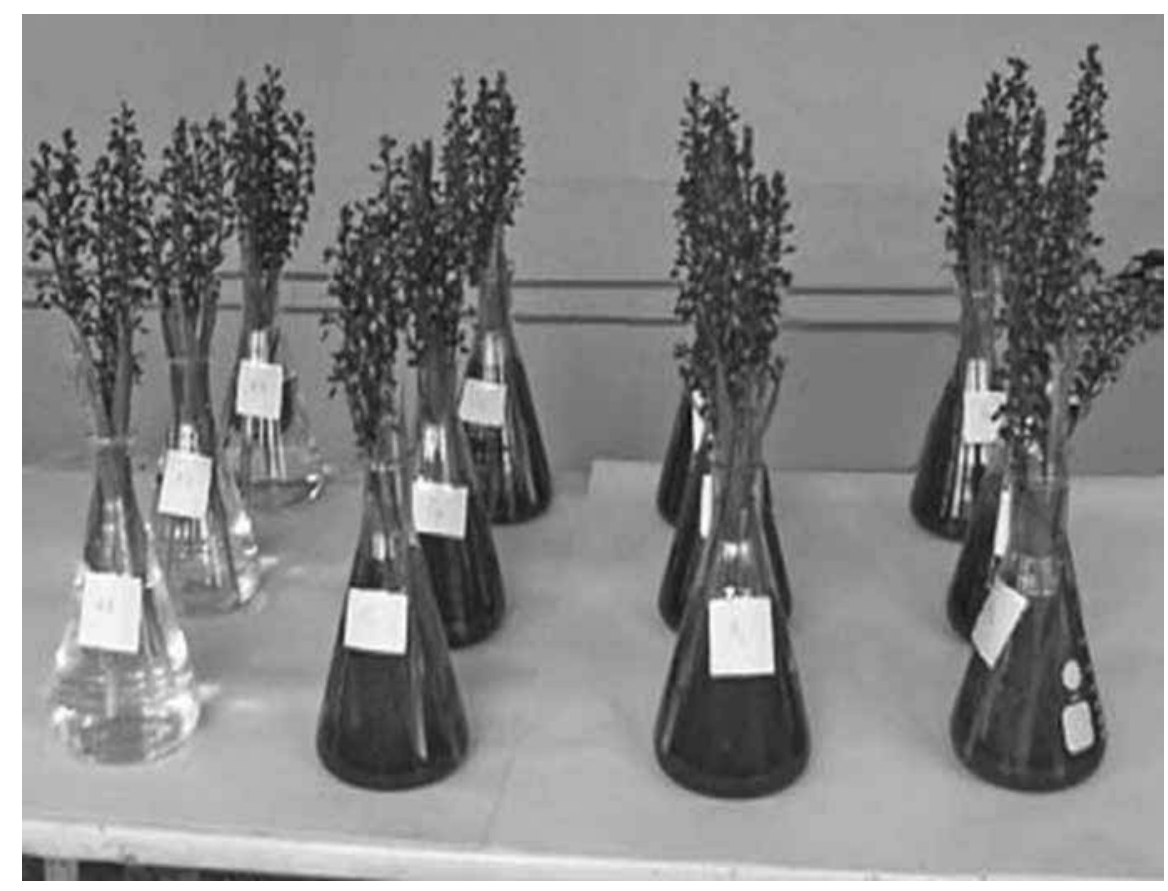

Figure 2. Orchis palustris plants in the laboratory.

Variations in the amount of solution: Diluted substance rates in the vases showed variations depending on humidity and temperature. $1-\mathrm{L}$ baseline levels of solutions were marked on the vase. Loss of solution levels was determined by measuring these levels every other day at the same time. All levels were adjusted to $1 \mathrm{~L}$ by adding extra solution (Meeteren and Gelder, 1999).

PH variations of the solutions: $\mathrm{pH}$ level variationsis one of the factors affecting the shelf life length of cut flowers (Put and Meijden, 1988). Variations in $\mathrm{pH}$ of each of the solutions was determined by measuring $\mathrm{pH}$ levels when solutions were first prepared (at the baseline; $1^{\text {st }}$ day), in the middle of the and at the end of the ( $11^{\text {th }}$ day and $21^{\text {st }}$ to $23^{\text {rd }}$ days respectively) possible length of vase life.

Variations in stem thickness: Thickness of the flower stems measured before exposure to solution showed variations depending on the time when flowers were placed into vases. (Lee and Lee, 1989). 
This variable was also measured regularly during the study period.

Variations in flower length: Length of flowers is an important factor in determining cut flower quality. Flower length was measured at the beginning of the study. After the first measurement, variations in flower length were measured regularly in two-day intervals in order to monitor the flowers which did not blossom in the rate of $10 \%$.

Flower variations: Reduction in flower radius was measured regularly in order to follow contractions due to fading. Samples were labelled as dead when the number of dead florets exceeded half of the span of their radius which was determined to be the end of vase or shelf life. The number of dead flowers was regularly measured until the end of vase life.

Statistical analysis: The experimental design was randomized with three replications. Data were subjected to variance analysis using SPSS statistical software. Differences in solution content applications were tested using the LSD test.

\section{RESULTS AND DISCUSSION}

Stem thickness and flower length of A,B and C varied and the control solutions, and $\mathrm{pH}$ also showed great variations. The average temperature and relative humidity were measured at $18.5{ }^{\circ} \mathrm{C}$ and $68 \%$ during the study, respectively. Solution losses measured every other day increased with time. The maximum loss of solution occurred on the $13^{\text {th }}$ day, with the exception of the control. Towards the end of the study period, this increase ceased and losses decreased with a reduction in the number of flowers in the vases. Flowers treated with solution $\mathrm{C}$, exhibited the lowest solution loss on the $3^{\text {rd }}$ day of the study period with $20.6 \mathrm{ml}$ while the maximum solution loss occurred on $13^{\text {th }}$ day with 29.6 $\mathrm{ml}$ compared to the other solutions (Figure 3).

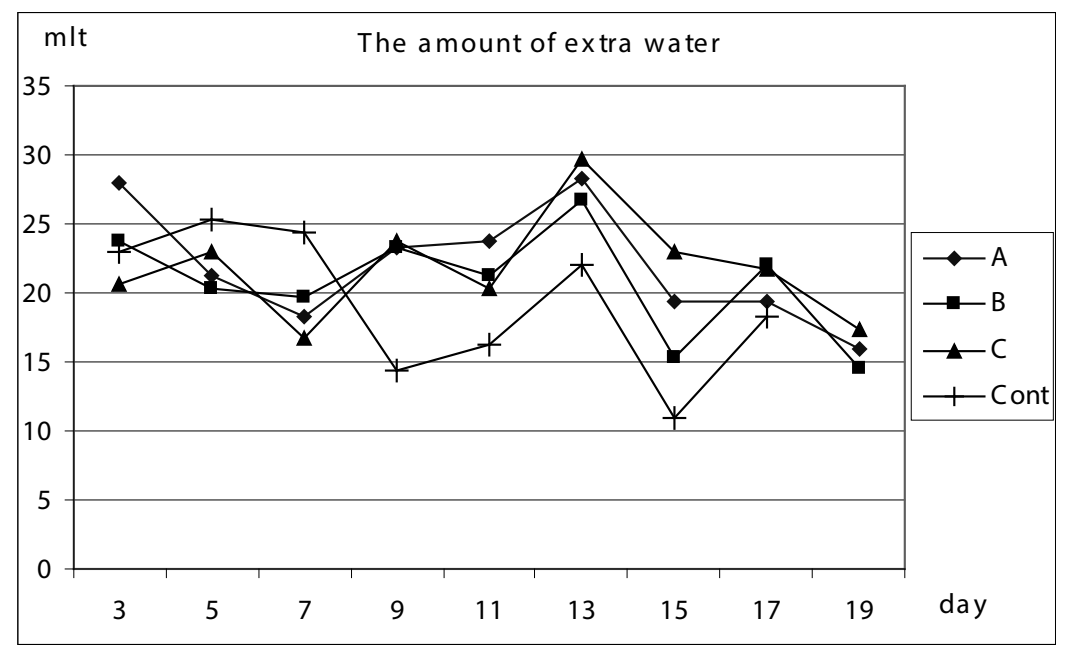

Figure 3. Solution losses of vases.

$\mathrm{pH}$ values of solutions were measured before putting flowers into vases. $\mathrm{pH}$ value of solution A was 4.72, the lowest among the solutions, and the highest $\mathrm{pH}$ was tap water with a value of 7.27. In the middle of study period, on the $13^{\text {th }}$ day, the $\mathrm{pH}$ of all of the solutions showed a decreasing trend while at the end of the period, the $\mathrm{pH}$ of all of the solutions continued to decrease with the lowest $\mathrm{pH}$ of 3.80 in solution $\mathrm{B}$.
The control vase showed a different trend in $\mathrm{pH}$ values from the other solutions by having a slight decrease at first, then stabilizing and increasing at the end exceeding the baseline value of 7.76 (Figure 4). Results of the statistical analysis showed that there is a negative relationship between the life length of flowers and $\mathrm{pH}$ in all solutions. Acidity increased life length of the flowers. 


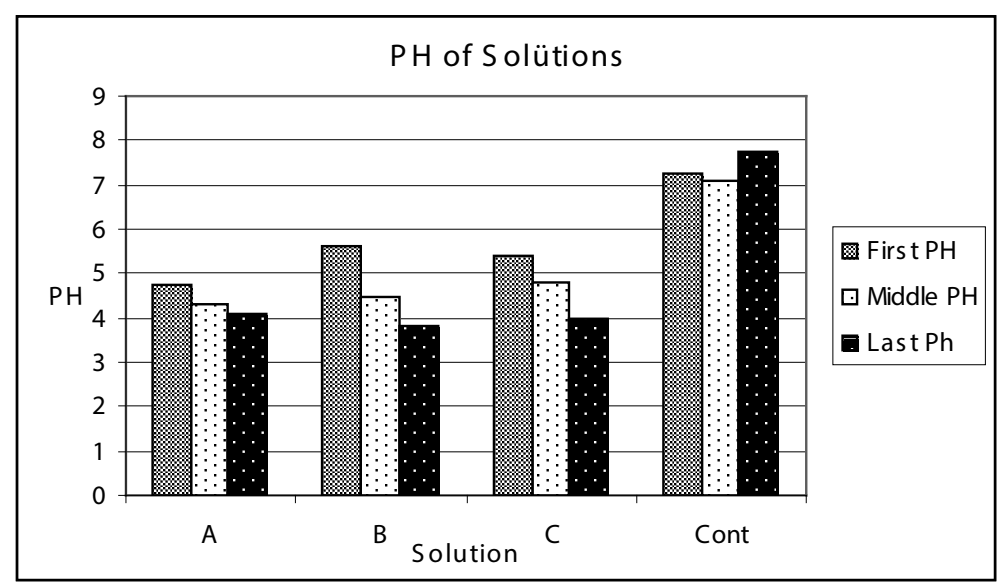

Figure 4. $\mathrm{pH}$ changes in solutions

Another variable evaluated in the study was stem thickness, which showed a decreasing trend towards the end of the study period for all treatments. For instance, the stem thickness of flowers in solution B was $0.83 \mathrm{~cm}$ when they were put into a vase, which was the highest mean value among the samples, with a value of $0.76 \mathrm{~cm}$ at the end of the study.
Flower length is an important factor for cut flowers. The highest mean flower length at the beginning was measured at $21.1 \mathrm{~cm}$ in solution B while the control had the lowest value at $19.4 \mathrm{~cm}$. The highest increase in flower length was $2.5 \mathrm{~cm}$ in solution $\mathrm{C}$ while the lowest increase was $0.7 \mathrm{~cm}$ in the control in the end of study (Figure 5).

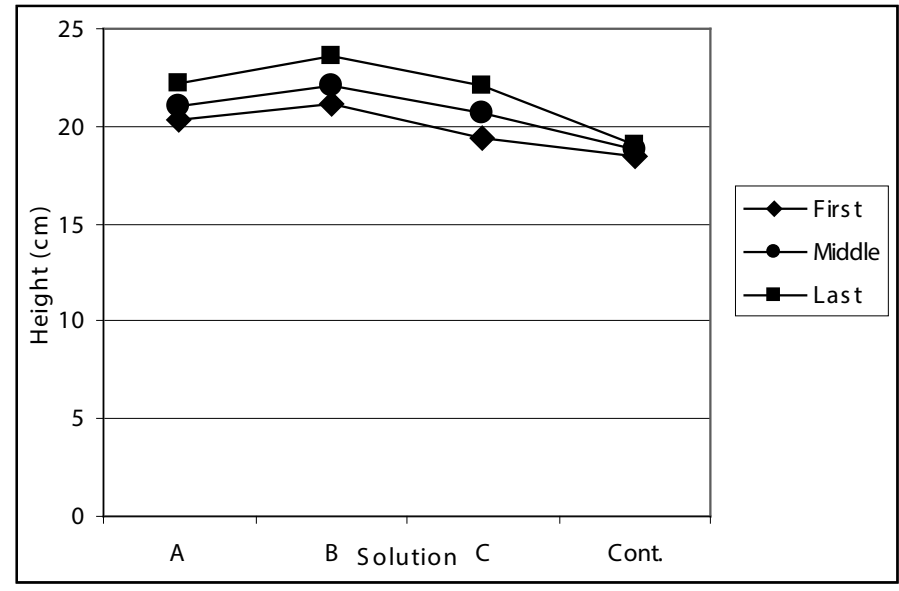

Figure 5. Changes in flower length in time

The radius of flowers was measured before they were put into vases and measurements were taken throughout the study period. Mean radius values were $3.1 \mathrm{~cm}, 3.2 \mathrm{~cm}, 3.2 \mathrm{~cm}$ and $3.2 \mathrm{~cm}$ in A, B, C solutions and the control, respectively whereas these values were $2.26 \mathrm{~cm}, 2.30 \mathrm{~cm}, 2.50 \mathrm{~cm}$ and $2.73 \mathrm{~cm}$ in solutions A, $\mathrm{B}, \mathrm{C}$ and the control when flowers began to die.

In the measurements conducted as flowers began to die, the maximum reduction in flower radius was found to be $0.9 \mathrm{~cm}$ in solution $\mathrm{B}$ while the minimum was seen in control with $0.7 \mathrm{~cm}$. When considering the length of vase life, the shortest vase life was seen in the control with 14.6 days while the longest was in solution B with 23.0 days, which was followed by solution $A$ and $C$ with 21.06 and 21.0 days. Solution B increased life length by 8.4 days $(57.5 \%)$ as compared to the control while solutions A and C caused an increase of 6.46 (44.2\%) and 6.40 (43.8\%) days, respectively (Figure 6). 


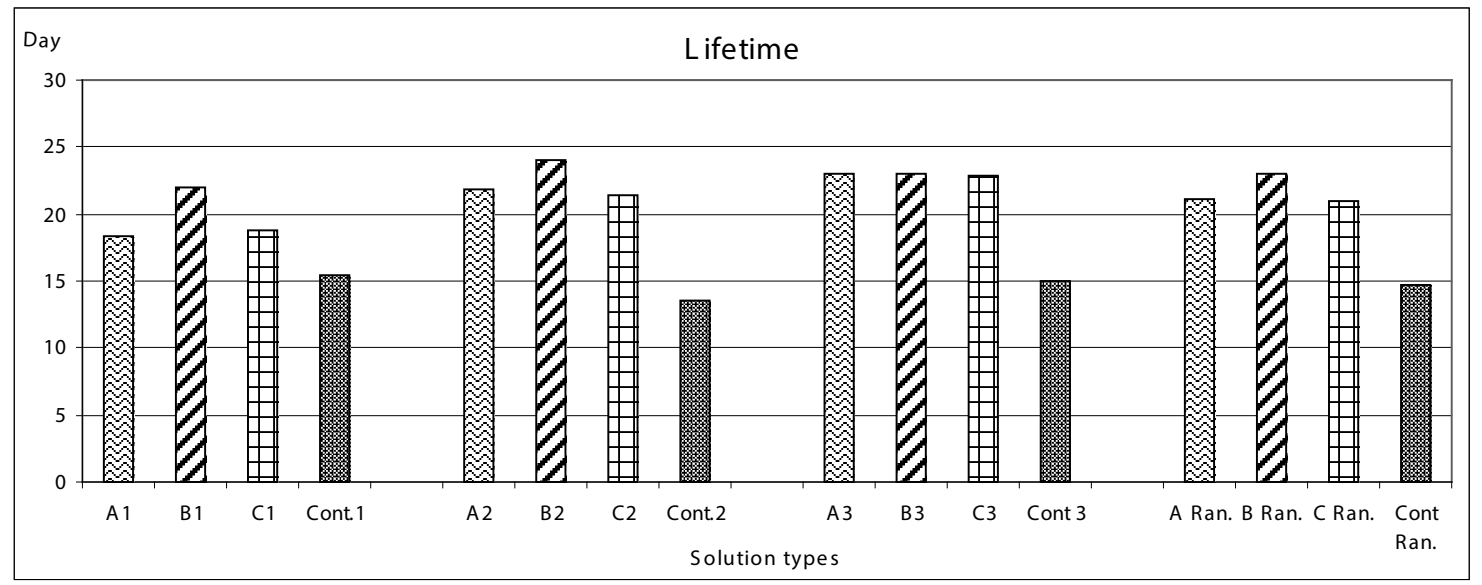

Figure 6. Relationship between solution types and vase life

There were significant differences among the three solutions and the control $(\mathrm{P}<0.01)$. The relationship between life length and $\mathrm{pH}$ was significant at the beginning of study, while very significant in the middle of the and at the end of the study. The difference in flower radii between the beginning and the end of study period was very significant (Table 2).

Table 1. Relationships among parameters of Orchis palustris $\left(\mathrm{p}<0.01^{* *}\right)$

\begin{tabular}{|c|c|c|c|c|c|c|c|c|c|c|}
\hline & 1. & 2. & s. & 4 & s. & a. & 7. & 8 & 9. & 10. \\
\hline 1 flowerlife & & 0.52 & $0.59^{\circ}$ & -0.05 & $-0,6 \theta^{\circ}$ & $-0,79^{-}$ & $-0,8 \sigma^{\circ}$ & 0.02 & 0,007 & $-0,32$ \\
\hline 2 flowerdismeterfir st & & & $0.88-$ & -0.18 & -0.22 & -0.34 & $-0,35$ & -0.02 & -0.29 & $-0,53$ \\
\hline S flowerdiametermid dle & & & & 0.29 & $-0,06$ & -0.23 & $-0,20$ & 0.25 & -0.11 & $-0,28$ \\
\hline 4 flowerdiameter end & & & & & 0.39 & 0.30 & 0,41 & $0,64^{*}$ & 0.27 & 0,41 \\
\hline 5.pHfirst & & & & & & $0.95-$ & $0.95^{* *}$ & 0.31 & 0,15 & 0,49 \\
\hline 6.pHmiddle & & & & & & & 0,97 & 0.23 & 0.20 & $0,61^{-}$ \\
\hline 7.pHend & & & & & & & & 0.28 & 0,12 & 0.53 \\
\hline 8.stemthiclonessfirst & & & & & & & & & 0,62 & 0.28 \\
\hline 9.stemthiclonessmid dle & & & & & & & & & & $0,71^{1 *}$ \\
\hline 10.stemthielonesend & & & & & & & & & & \\
\hline
\end{tabular}

Flora of Turkey is rich in plant diversity. Most studies were carried out to determine and use the flowers grooving in Turkey (Yücel and Altınöz 2001; Zencirkıran 2005; Kılıç et al., 2006; Özer et al., 2009; Düşen and Sümbül 2007; Koyuncu et al., 2011; Bektaş et al., 2013). Therefore extending the vase life of these wild flowers in Turkey are becoming increasingly important for cut flower production. Various factors are well known to effect the vase life length of cut flowers. Physical factors such as humidity and temperature were the same for all solution types in the vases; these factors remained constant. Variations in the vase life length caused by solutions A, B, C and the control were evaluated. Solutions used by 
Y1lmaz (1991) were also applied in the present study and results are consistent with those of Ketsa (1995), Ichimura et. al. (1999), Onozaki et al. (2001), Paul and Chantrachit (2001), Capdeville (2005) and Macnish et al. (2008), all of which found that various solutions increased life length of Orchis palustris compared to that of tap water (control).

The study revealed a significant relationship between flower length and $\mathrm{pH}$ and solution loss. The life length of flowers in solutions with a lower $\mathrm{pH}$ was longer. The solution which exhibited the longest vase life length was solution $\mathrm{B}$ with a $\mathrm{pH}$ value of 3.80, which was lower than that of $\mathrm{A}$ and $\mathrm{C}$. The $\mathrm{pH}$ of the control solution was determined to be 7.27 at the beginning, which showed a decrease until the $13^{\text {th }}$ day when flowers began to die and the $\mathrm{pH}$ increased to 7.76. It is clear that the $\mathrm{pH}$ of solution $\mathrm{B}$, which provided the longest vase life, was the lowest while the control with the shortest vase life had the highest $\mathrm{pH}$. This shows a clear negative relationship between $\mathrm{pH}$ and vase life length.

A relationship was found between the flower stems and life length of flower. Solution B provided the longest life for flowers with a radius of $0.9 \mathrm{~cm}$, whereas control solution provided the lowest reduction with $0.7 \mathrm{~cm}$ and shortest life length.

A close relationship was also obtained between vase life length and solution losses. On the $15^{\text {th }}$ day of the study, total loss in solution B was the lowest compared to solutions $\mathrm{A}$ and $\mathrm{C}$, with $150 \mathrm{ml}$. At the beginning of fading period, which was $21^{\text {st }}$ day, loss in solution B was the lowest with $198.9 \mathrm{ml}$, which was followed by solution $\mathrm{C}$ and A with $203.6 \mathrm{ml}$ and $212 \mathrm{ml}$. This result shows that as the loss in solution reduces, life length increases which is not consistent with the findings of the study by Paul and Goo (1985) on Anthirium.

Solutions in general significantly increased the life length of flowers compared to tap water $(\mathrm{P}<0.01)$. This increase was seen in solution B $(150 \mathrm{mg} / \mathrm{L} 8-\mathrm{HQ}$, $100 \mathrm{mg} / \mathrm{L} \mathrm{AgNO}_{3} 80 \mathrm{mg} / \mathrm{L}$ sodium benzoate, $50 \mathrm{~g} / \mathrm{L}$ sugar, $20 \mathrm{mg} / \mathrm{L} \mathrm{AlSO}_{4}$ and $10 \mathrm{mg} / \mathrm{L}$ kinetin) at the highest with 23.0 days (57.5\%). When considered the solutions in the study, only kinetin is higher in solution $\mathrm{B}$ than $\mathrm{A}$ and $\mathrm{C}$. By considering this result, amount of solution $\mathrm{B}$, which is between $\mathrm{A}$ and $\mathrm{C}$, can be accepted to be more suitable. In addition, use of kinetin more in this solution than $\mathrm{A}$ and $\mathrm{C}$ can be said to have favourable effects on the length of flower. This study showed that in addition to its attractive features, Orchis palustris is a good quality vase flower which can be vivid for 14.6 days even in tap water.

Vase flowers sold in the region are brought from outside the region. It was found in the study that Orchis palustris is a good quality vase flower with its flower characteristics and vase life. Therefore, it can be used as a new cut-flower for these favourable features; to meet cut flower need of its native region; and to be exported to other neighbouring regions and countries.

\section{REFERENCES}

Anonymous, 2009. Kesme Çiçek Sektör Raporu. T.C. Başbakanlık Devlet D1ş Ticaret Müsteşarlığı, İhracat Genel Müdürlüğü, p. 24. Ankara.

Al-Humaid, 2004. Silver Thisulfate Prolongs Vase Life and Improves Quality of Cut Gladiolus and Rose Flowers. Journal of Food, Agriculture and Environment, p. 296-300, Buraidah, Suidi Arabia.

Bektaş E, Cüce M., Atalay S, 2013. In vitro germination, protocorm formation, and plantlet development of Orchis coriophora (Orchidaceae), a naturally growing orchid species in Turkey. Turk J Bot 37: 336-342.

Capdeville De G, Maffia LA, Finger FL., Batista UG, 2005. Pre-harvest calcium sulfate applications affect vase life and severity of gray mold in cut roses. Scientia Horticulturae, 103/3: 329-338.

Darras AI, Terry LA, Joyce DC, 2005. Methyl jasmonate vapour treatment suppresses specking caused by Botrytis cinerea on cut Freesia hybrida L. Flowers. Postharvest Biology and Technology 38: 175-182.

Düşen OD, Sümbül H, 2007. A Morphological Investigation of Colchicum L. (Liliaceae) Species in the Mediterranean Region in Turkey. Turk J Bot 31:373-419.

Eken C, Ercişli S, Eşitken A, Demirci E, Yuen GY, 2005. First report of crown and stem rot of orchid (Orchid palustris) caused by Sclerotinia minor. Plant Disease, 89/8: 913.

Groot NSP, 1998. "Floricultura Worldwide Trade and Consuption Patterns", World Conference on Horticulture Research, 75-99, Roma.

Gomiz NE, Torretta JP, Aliscioni SS, 2013. Comparative anatomy of elaiophores and oil secretion in the genus Gomesa (Orchidaceae). Turk J Bot 37: 859-871.

Hew CS, 1994. Orchid cut-flower production in ASEAN countries, In: Arditti, J. (Ed.), Orchid Biology: Reviews and Prospectives, Vol. VI. Wiley, New York, 363-401. 
Kazuo-Ichimura K, Kojima K, Goto R, 1999. Effects of temperature, 8-hydroxyquinoline sulphate and sucrose on the vase life of cut rose flowers. Postharvest Biology and Technology, 15/1: 33-40.

Ketsa S, Boonrote A, 1990. Holding solutions for maximizing bud opening and vase-life of Dendrobium 'Youppadeewan' flowers. J. Hortic. Sci. 65: 41-47.

Ketsa S, Piyasaengthong Y, Prathuangwong S, 1995. Mode of action of $\mathrm{AgNO}_{3}$ in maximizing vase life of Dendrobium 'Pompadour' flowers. Postharvest Biology and Technology, 5/1-2: 109-117.

Ketsa S, Uthairatanakij A., Prayurawong A, 2001. Senescence of diploid and tetraploid cut inflorescences of Dendrobium 'Caesar'. Scientia Horticulturae, 91/1-2:133-141.

Kı1ıç S, İnce A., Özçelik H, 2006. Türkiye'nin Ekonomik Değer Taşıyan Geofitlerinden Corydalis solida subsp. Solida ve Corydalis onorhiza (Fumariaceae)'nin Anatomik Özellikleri. Ekoloji (FEPR), 15/60: 46-54.

Kiziroğlu İ, Ekim, T., Özgül C, 1992. Türkiye'nin Biyolojik Zenginlikleri ve Tehdit Altındaki Canlı Türleri. Tabiat ve İnsan, 2: 5-13.

Koyuncu O, Yaylacı ÖK, Öztürk D, Potoğlu Erkara İ, Savaroğlu F, Osoydan K., Ardiç M, 2011. Distribution, Elements of Destruction and Evaluation of Risk Categories of Orchids In Osmaneli (Bilecik/Turkey) and Its Environs. BioDiCon 4/1: 122-133.

Machaka-Houri N, Al-Zein MS, Westbury DS, Talhouk SN, 2012. Reproductive success of the rare endemic Orchis galilaea (Orchidaceae) in Lebanon. Turk J Bot 36: 677-682.

Macnish A J, Leonard RT, Nell T A, 2005. Treatment with chlorine dioxide extends the vase life of selected cut flowers, Postharvest Biology and Technology 50: 197-207.

Meeteren UV, Gelder HV, 1999. Effect of time since harvest and handling conditions on rehydration ability of cut chrysanthemum flowers. Postharvest Biology and Technology 16: 169-177.

Onozaki T, Ikeda H., Yamaguchi T, 2001. 5-Genetic improvement of vase life of carnation flowers by crossing and selection. Scientia Horticulturae, 87/1-2: 107-120.

Özer S., Y1lmaz H, Kaya Y, 2009. Determination of The Diversity of Grassy and Woody Plant Species In Sarıkamıș/Turkey District and Evaluation of Their Usability In Planning and Design Attempts. BioDiCon 2/3:75-81.

Paull RE, Chantrachit T, 2001. 4-Benzyladenine and the vase life of tropical ornamentals. Postharvest Biology and Technology. 2173: 303-310.

Paull RE, Goo, 1985. Ethylene and water stress in the senescence of cut anthurium flowers. J. Amer. Soc. Hort. Sci. 110: 84-88.

Sahamantak M, Pathania NS, 2003. Effect of Pulsing Treatments on Post Harvest Characters of Gladiolus. Horticultural Abstract. 73/3: (2748).

Selvi S, Erdoğan E, Daşkın R, 2008. Hyacinthella lineata (Liliaceae) Üzerinde Morfolojik, Anatomik ve Ekolojik Araştırmalar. Ekoloji (FEPR), 17/68: 24-32.

Singh AK, Chetan S, 2004. Effect of Spacing and Zinc on Grawth and Flowering in Gladiolus Cultivated Sylvia. Progressive Horticulture, 36/1: 94-98,
Wilson RF, 1938 “The Wilson Colour Chart”, Vol:I-II, syf: 89-90127-128.

Y1lmaz H, 1991. Bazı Kesme Çiçeklerde (Rosa hybrida var. Baccara, Dianthus caryophyllus var. Pink Sim, Gerbera jamesonii var. Fleur ve Gyysophila elegans L.) Madde Uygulamaları ile vazoda Dayanma Sürelerinin Uzatılması. Atatürk Üniv. Fen Bilimleri Enstitüsü Bahçe Bitkileri Anabilim Dalı, Yüksek Lisans Tezi, s. 60, Erzurum

Yücel E, Altınöz N, 2001. Salvia wiedemannii'nin Ekolojik Özellikleri. Ekoloji (FEPR), 10/38: 9-17.

Zencirkıran M, 2005. Effects of Sucrose and Silver Thiosulphate Pulsing on Stem-Base Cracking and Vase-Life in Leucojum aestivum Flowers. Journal of Horticultural Science and Biotechnology, 80/3: 332-334. 